\title{
Kualitas Mikrobiologis Daging Unggas di RPA dan yang Beredar di Pasaran
}

\author{
Microbiological Aspect of Poultry Meat in the poultry slaughterhouses (RPA) and Traditional Market \\ Dewi ES, El Latifa S, Fawwarahly, dan R Kautsar \\ Mahasiswa Sekolah Pascasarjana, Departemen Ilmu Produksi dan Teknologi Peternakan, IPB
}

\begin{abstract}
The aim of this study is to determine the microbiological aspect of meat from slaughterhouses to the consumer and to identify the factors and solutions in handling the contamination of meat. In this study the number of psychrotrophs, E, coli, S. aureus in purchased meat in traditional markets and RPA artisanal, has exceeded reasonable limits set out in the guidelines (1996) CNERNA-CNRS poultry meats. Thus in the samples purchased in these sites were regarded as unacceptable quality. Meanwhile Sixty-six samples of chicken meat collected from retailers, 21 samples of chicken breast without skin, 19 samples of chicken breast with skin, and 26 samples of frozen chicken meat 'ground'. The results of analysis, the percentage of Salmonella spp. $10.60 \%$; S. Auerus amounted to $30.30 \%$; enterobacteria at $24.84 \%$; $\mathbf{L}$. monocytogenes at $3.03 \%$; and clostridium sulfate at $1.5 \%$. It could not been found any contamination of Campylobacter spp. in the samples.
\end{abstract}

Keywords: microbiology, poultry meat, poultry slaughterhouse

\section{PENDAHULUAN}

\section{Latar Belakang}

Daging adalah salah satu pangan asal hewan yang mengandung zat gizi yang sangat baik untuk kesehatan dan pertumbuhan manusia, serta sangat baik sebagai media pertumbuhan mikroorganisme. Daging (segar) juga mengandung enzim-enzim yang dapat mengurai/ memecah beberapa komponen gizi (protein, lemak) yang akhirnya menyebabkan pembusukan daging. Oleh sebab itu, daging dikategorikan sebagai pangan yang mudah rusak (perishable food). Beberapa penyakit hewan yang bersifat zoonosis (penyakit yang dapat ditularkan dari hewan kepada manusia) dapat ditularkan melalui daging (meatborne disease). Selain itu, daging juga dapat mengandung residu obat hewan dan hormon, cemaran logam berat, pestisida atau zat-zat berbahaya lain, sehingga daging juga dikategorikan sebagai pangan yang berpotensi berbahaya bagi kesehatan manusia (potentially hazardous food/PHF). Agar daging tetap bermutu baik, aman dan layak untuk dikonsumsi, maka perlu penanganan daging yang aman dan baik mulai dari peternakan sampai dikonsumsi. Konsep tersebut dikenal sebagai safe from farm to table concepts.

Salah satu tahap yang sangat menentukan kualitas dan keamanan daging dalam mata rantai penyediaan daging adalah tahap di rumah pemotongan hewan (RPH). Di RPH ini hewan disembelih dan terjadi perubahan (konversi) dari otot (hewan hidup) ke daging, serta dapat terjadi pencemaran mikroorganisme terhadap daging, terutama pada tahap eviserasi (pengeluaran jeroan). Penanganan hewan dan daging di RPH yang kurang baik dan tidak higienis akan berdampak terhadap kehalalan, mutu dan keamanan daging yang dihasilkan. Oleh sebab itu, penerapan sistem jaminan mutu dan keamanan pangan di RPH sangatlah penting, atau dapat dikatakan pula sebagai penerapan sistem product safety pada RPH. Aspek yang perlu diperhatikan dalam sistem tersebut adalah higiene, sanitasi, kehalalan, dan kesejahteraan hewan.

Penerapan product safety pada RPH ditujukan untuk memberikan jaminan keamanan dan mutu daging yang dihasilkan, termasuk kehalalan, dalam rangka memberikan perlindungan terhadap konsumen, serta turut menjaga kesehatan manusia dan lingkungan. Selain itu, sistem tersebut berfungsi sebagai pengawasan dan pengendalian penyakit hewan dan zoonosis di RPH sebagai bagian dari sistem kesehatan hewan nasional. Penulisan makalah ini bertujuan untuk mengetahui mengetahui kualitas mikrobiologis daging dari lokasi rumah pemotongan hewan sampai ke konsumen dan mengetahui faktor-faktor dan solusi untuk menangani kontaminasi daging.

\section{PEMBAHASAN}

Aspek Mikrobiologis Daging ayam

Bahan mentah asal unggas seringkali terkontaminasi oleh mikroba patogen penyebab foodborne diseases seperti Salmonella, Staphylococcus aureus, Clostridium perfrigens, dan Campylobacter fetus subs jejuni dan Yersiniea enterocolitica. Menurut Quinn et al. (2002), foodborne diseases yang disebabkan oleh organisme dapat dibagi menjadi dua kelompok besar yaitu infeksi makanan dan keracunana makanan. Infeksi makanan terjadi karena mengkonsumsi makanan yang mengandung organisme hidup yang mampu berkembang biak di dalam usus, dan menimbulkan penyakit. Organisme penting yang menimbulkan infeksi makanan meliputi 
C. Perfringens, Vibrio parahaemolyticus, dan sejumlah Salmonella. Keracunanan makanan tidak disebabkan tertelannya organisme hidup melainkan akibat masuknya toksin atau substansi beracun yang disekresikan ke dalam makanan. Organisme penghasil toksin tersebut mati setelah pembentukan toksin dalam makanan. Organisme yang menyebabkan keracunanan makanan meliputi $S$. areus, $C$ botulinum, dan Bacillus cereus.

Kontaminasi selanjutnya terjadi melalui permukaan daging selama proses mempersiapkan daging, yaitu proses pembelahan karkas, pendinginan, pembekuan, penyegaran daging beku, pemotongan karkas, pembuatan produk daging olahan, pengawetan, pengepakan, penyimpanan, dan pemasarannya (Soeparno 1992).

Proses pengeluaran jeroan memberikan banyak kesempatan vagi kontaminasi bakteri baik dari usus maupun dari feses yang dapat dipindahkan dari karkas ke karkas, melalui pisau, kapak, dan tangan pekerja. Kontaminasi tidak hanya terdapat pada bagian luar karkas, tetapi juga permukaan rongga karkas (Dirjennak 1992).

\section{Batas Maksimum Cemaram Mikroba Pada Daging}

Menurut Standar Nasional Indonesia (2000) batas maksimum cemaran mikroba adalah jumlah jasad renik/mikroba maksimum (CFU/gr) yang diijinkan atau direkomendasikan dapat diterima dalam bahan makanan asal hewan (Tabel 1).

\section{Total Mikroba}

\section{Jenis Cemaran Mikroba Daging Unggas}

Bahan pangan seperti daging ayam dapat bertindak sebagai substrat untuk pertumbuhan dan perkembangbiakan spesies mikroba patogen yang dapat menyebabkan penyakit bagi manusia yang memakannya. Penyakit yang ditimbulkannya terbagi menjadi dua kelompok yaitu infeksi dan intoksikasi (keracunan). Infeksi merupakan tertelannya mikroba dan mikroba tersebut berkembang biak dalam alat pencernaan. Gejala-gejala yang timbul ditandai dengan sakit perut, pusing, muntah dan diare (Buckle et al. 1987). Sekitar $70 \%$ penyakit diare dianggap disebabkan oleh makanan yang mengandung penyakit (Winarno 2004). Kelompok kedua adalah intoksikasi (keracunan). Intoksikasi merupakan

Tabel 1 Spesifikasi persyaratan mutu batas maksimum cemaran mikroba pada daging $(\mathrm{CFU} / \mathrm{g})$

\begin{tabular}{lll}
\hline $\begin{array}{l}\text { Jenis cemaran } \\
\text { mikroba }\end{array}$ & $\begin{array}{l}\text { Batas maksimum cemaran mikroba } \\
\text { (BMCM) } \\
\text { Daging segar } \\
\text { beku }\end{array}$ & Daging tanpa tulang \\
\hline $\begin{array}{l}\text { Jumlah total kuman } \\
\text { (total palte count) }\end{array}$ & $1 \times 10^{4}$ & $1 \times 10^{4}$ \\
Coliform & $1 \times 10^{2}$ & $1 \times 10^{2}$ \\
Escherichia coli* & $5 \times 10^{1}$ & $5 \times 10^{1}$ \\
Enterococci & $1 \times 10^{2}$ & $1 \times 10^{2}$ \\
Staphyloccus aerus & $1 \times 10^{2}$ & $1 \times 10^{2}$ \\
Clostridium sp & 0 & 0 \\
Salmonella sp $* *$ & Negatif & Negatif \\
Camphylobacter sp & 0 & 0 \\
Listeria sp & 0 & 0 \\
\hline
\end{tabular}

tertelannya racun yang dihasilkan terlebih dahulu oleh pertumbuhan mikroba dalam bahan pangan. Data statistik di Inggris, Amerika Serikat, dan Australia menunjukkan bahwa kira-kira 70\% dari wabah keracunan karena bahan pangan dihubungkan dengan konsumsi produk daging dan ayam (Buckle et al., 1987).

\section{E.coli}

E.coli pertama kali dikenalkan oleh seorang ilmuwan bernama Theodor Escherich pada tahun 1885 dengan nama Bacterium coli cummune yang diisolasi dari feses seorang bayi (Todar 2008a). E coli merupakan bakteri gram negatif, dapat tumbuh dalam non-enrich media, bersifat oksidase positif, fakultatif anaerob, memfermentasi glukosa, dan mengubah nitrat menjadi nitrit. Selain itu E.coli kebanyakan motil dilengkapi dengan peritrichous flagella dan kadang fimbriae. E.coli dalam bidang mikrobiologi pangan, dikenal dengan istilah bakteri indikator sanitasi. Bakteri indikator sanitasi adalah bakteri yang keberadaannya dalam pangan menunjukkan bahwa pangan tersebut pernah tercemar oleh kotoran manusia dan atau hewan karena bakteri-bakteri tersebut lazim terdapat dan hidup pada usus manusia. Sampai saat ini ada 3 jenis bakteri yang dapat digunakan untuk menunjukkan adanya masalah sanitasi yaitu E.coli, Streptococcus, (Enterococcus) fekal, dan C. Prefringens (Hariyadi 2005).

Beberapa galur E.coli yang dapat menyebabkan penyakit pada manusia adalah enteropathogenic E.coli (EPEC), enterotoxigenic E.coli (ETEC), enterohaemorrhagic E.coli (EHEC), enteroinvasive E.coli (EIEC) dan enteroaggregative E.coli (EAEC).

\section{Staphylococcus aureus}

S.aureus ditemukan pertama kali di Aberdeen, Skotlandia pada tahun 1880 oleh seorang ahli bedah yang bernama Sir Alexander Ogston (Todar 2008c). S. aureus merupakan salah satu mikroflora normal pada unggas dan ternyata pengolahan yang baik tidak sepenuhnya menjamin dapat mencegah kontaminasi oleh S.aureus. meskipun demikian, Staphylococci tidak mampu bersaing dengan baik melawan mikroba pembusuk normal lainnya yang terdapat pada unggas dan tidak mungkin berkembang biak pada karkas beku. Adanya S.aureus dalam daging ayam menunjukkan kontaminasi melalui alat/mesin pencabut

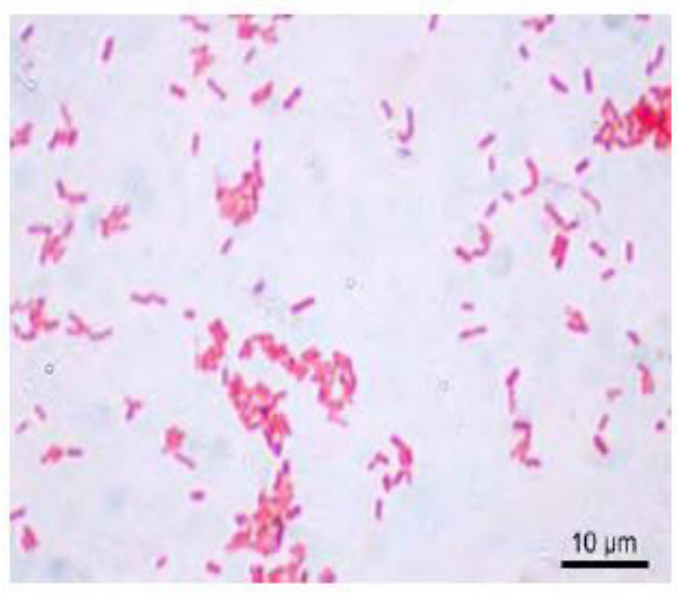

Gambar 1 Escherichia coli (Todar 2008a) 
bulu (ICMFS 1986).

S. aureus merupakan bakteri gram positif berbentuk kokus yang tersusun dalam kluster yang tidak teratur jika ditumbuhkan dalam media padat. Menurut Todar (2008c), S.aureus bersifat fakultatif anaerob dan berbentuk kluster seperti anggur, besar, bulat, koloni berwarna kuning keemasan, kadang menyebabkan hemolisis jika ditumbuhkan pada gara darah dan bersifat katalase positif. Staphylococcal food poisoning (SFP) merupakan penyebab utama gastroenteritis di seluruh dunia. Penyebab utamanya adalah genus Stapylococcus terutama S.aureus yang menghasilkan Staphylococcal enterotoxins (Ses) yang tahan panas dalam makanan yang terkontaminasi (Doyle et al. 2001). Menurut Shah (2003), S.aureus menghasilkan 2 tipe toksin yaitu enterotoksin dan toxic shock syndrome toxin (TSST-I). Enterotoksin bertanggung jawab terhadap SFP, sementara TSST-I bertanggung jawab terhadap toxic shock syndrome (TSS).

\section{Salmonella}

Menurut hariyadi (2005), Salmonella merupakan bakteri indikator keamanan pangan artinya karena semua serotipe salmonella yang diketahui di dunia ini bersifat patogen maka adanya bakteri ini dalam pangan dianggap membahayakan kesehatan. Menurut Brooks et al. (2005), Salmonella menyebabkan 3 tipe penyakit utama pada

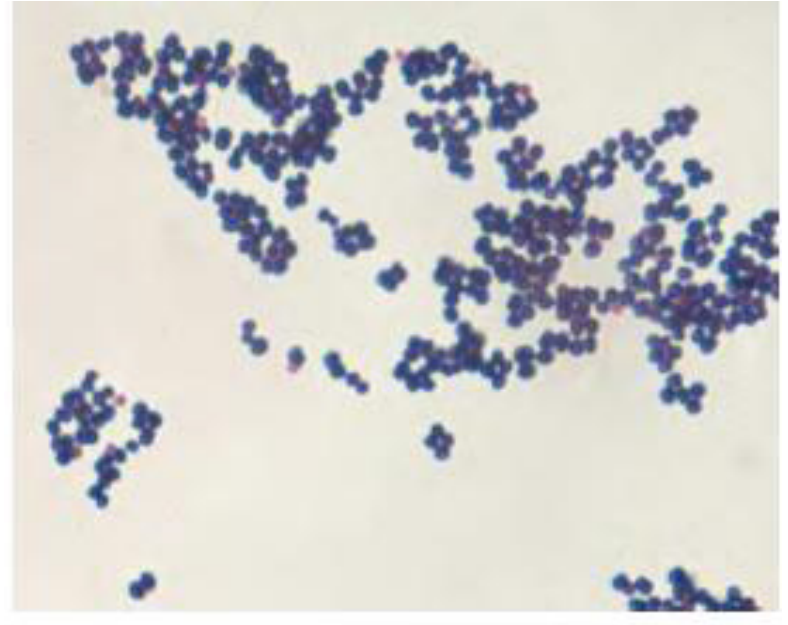

Gambar 2 Staphylococcus aureus (Todars 2008c)

manusia yaitu demam enterik (demam typoid), bakteremia dengan luka fokal dan enterokolitis. Enterokolitis merupakan manifestasi infeksi Salmonella yang wajar. Delapan sampai 48 jam sesudah menelan salmonella, akan terasa mual,sakit kepala, muntah dan diare.

Kuman Salmonella yang menyerang unggas adalah S. pullorum, S. gallinarum, dan S. typhimurium. Infeksi Salmonella pada manusia bervariasi tergantung oleh serovar, strain, dosis infeksi, jenis makanan yang terkontaminasi, dan status host. Sumber penularan dan penyebaran Salmonella terutama dari penderita baik hewan maupun manusia. Penderita salmonellosis akan menyebar dan mencemari lingkungan lewat ekskresi berupa tinja, yang dilanjutkan akan menyebar dan mencemari lingkungan, alat pakan, benda-benda lain di sekitar unggas dan bahan makanan tersebut. Daging yang terkontaminasi (sapi, babi, kambing, ayam) dapat berasal dari salmonellosis pada hewan asalnya, tetapi seringkali dihasilkan dari kontaminasi pada daging dengan isi usus selama proses eviserasi, pencucian, dan transportasi karkas (Todar 2008b).

\section{Coliform}

Coliform merupakan bakteri yang diindikasikan dengan sanitasi yang jelek. Pencemaran coliform karena adanya kontaminasi yang bisa ditimbulkan dari tangan pekerja yang tidak bersih maupun air yang digunakan (Suryanto et al., 2005). Hasil penelitian Kaeratipibul et al. (2008) didapati bahwa kontaminasi

coliform paling tinggi, disebabkan oleh kontak langsung antara produk dan tangan-tangan pekerja. Selanjutnya Murphy (2004) menyatakan bahwa faktorfaktor yang dapat meningkatkan kandungan coliform antara lain : air limbah dan sistem saluran pembuangan, kotoran hewan, temperatur dan nutrien yang terkandung dalam bahan tercemar.

\section{Campylobacter sp.}

Campylobacter spp. merupakan bakteri gram negatif, motil dan tidak membentuk spora. Bakteri ini tumbuh pada kadar oksigen rendah serta tumbuh pada temperatur $32-45^{\circ} \mathrm{C}$ dan optimum pada $42{ }^{\circ} \mathrm{C}$. Bakteri ini sensitif terhadap panas, penggaraman, $\mathrm{pH}$ rendah dan kering. Mikroorganisme ini tahan pada suhu dingin dan beku (Ray dan Arun 2008). Penularan bakteri ini disebabkan oleh makanan yang menjadi sumber utama yaitu susu dan daging unggas mentah atau kurang matang. Penyakit yang disebabkan oleh bakteri Campylobacter $s p$ dikenal dengan nama campylobacteriosis. Penyakit tersebut ditandai dengan diare yang hebat disertai demam, kurang nafsu makan, muntah, dan leukositosis. Sekitar 70\% kasus campylobacteriosis pada manusia disebabkan oleh cemaran C. jejuni pada karkas ayam (Djafaar dan Rahayu 2007).

Faktor-faktor yang mempengaruhi pertumbuhan mikroorganisme pada daging

Segala sesuatu yang dapat berkontak dengan daging secara langsung atau tidak langsung, dapat merupakan sumber kontaminan. Kontaminasi ini dapat diatasi atau dikurangi dengan melakukan penanganan yang higienis dengan sistem sanitasi yang sebaik-baiknya. Besarnya kontaminasi mikroorganisme pada daging akan menentukan kualitas dan masa simpan daging proses (Soeparno, 2005). Faktor-faktor yang mempengaruhi pertumbuhan mikroorganisme pada daging ada dua macam, yaitu (a). Faktor intrinsik termasuk nilai nutrisi daging, keadaan air, $\mathrm{pH}$, potensi oksidasi-reduksi dan ada tidaknya substansi penghalang atau penghambat; (b). Faktor ekstrinsik, misalnya temperatur, kelembaban relatif, ada tidaknya oksigen dan bentuk atau kondisi daging (Fardiaz, 1992). Pengukuran secara tepat jumlah mikroorganis-me dalam daging ayam tersebut merupakan dasar yang penting untuk dilakukan. Hal ini dilakukan agar mikroorganisme yang dapat tumbuh pada daging ayam tidak melebihi batas maksimum cemaran mikroba.

\section{Kualitas Mikrobiologis Daging Unggas di RPA,} Selama distribusi, dan Pasar

Berdasarkan penelitian yang dilakukan oleh Arifin et al. (2008) diketahui bahwa sejak dari RPH daging sapi yang dihasilkan sudah dalam kondisi terkontaminasi bakteri 
dan selama proses distribusi kondisinya semakin memburuk. Tabel 2 menunjukkan penurunan kualitas daging dari jagal di RPH, pedagang pasar maupun konsumen diambil dari potongan paha yang berasal dari karkas yang sama. Variabel yang diamati meliputi total bakteri (TPC), kecepatan proses kebusukan (Uji Eber), dan volatile reduction substance (VRS).

Selama proses distribusi daging sapi asal RPH Kota Semarang mengalami penurunan kualitas yang cepat, hal ini dicerminkan oleh peningkatan total bakteri, kecepatan waktu proses kebusukan dan peningkatan kadar VRS (Tabel 2). Bahkan kualitas daging saat sampai di tangan konsumen secara mikrobiologis sudah tidak layak lagi untuk dikonsumsi. Kontaminasi bakteri dalam proses pemotongan ternak sangat mungkin terjadi, sebab proses pemotongan, khususnya pengulitan dan pengeluaran jerohan merupakan titik paling rentan terhadap terjadinya kontaminasi dari bagian luar kulit dan isi saluran pencernaan (Buckle et al. 1987).

Temuan peningkatan jumlah kontaminan bakteri di dalam daging sapi selama pasca pemotongan dimungkinkan terjadi karena proses pengangkutan dan cara menjajakan daging yang tidak memenuhi aspek higiene dan sanitasi. Kontaminasi bakteri pada daging sapi pada tingkat pedagang pasar ternyata bukan hanya terjadi di Indonesia. Di USA, Center for Disease Control and Prevention (1997) mengidentifikasi adanya kontaminan E. Coli O157 : H7 pada daging sapi beku yang beredar di pasar, semantara Radu et al. (1998) melaporkan adanya kontaminan E. Coli O157 : H7 pada daging sapi yang dijajakan pedagang pasar di Malaysia. Walaupun kejadian kontaminasi bakteri pada daging sapi tidak hanya ditemukan di Indonesia, namun kontaminasi bakteri pada daging sapi yang ditemukan di Kota Semarang tersebut sangat memprihatinkan, karena konsentrasinya sudah di atas SNI No. 01-3932-1995 (Direktorat Standarisasi Komoditi Pertanian, 2000).

Hasil uji Eber dan VRS pada penelitian ini juga mengindikasikan kehadiran bakteri pembusuk pada daging sapi saat sampai ke tangan konsumen sudah berkembang lebih cepat dibandingkan dengan waktu dari RPH maupun pedagang pasar. Seperti diketahui kebusukan daging sapi dapat terjadi karena: (1) aktivitas mikroorganisme; (2) ketersediaan oksigen dari lingkungan tempat menyimpan daging; dan (3) kandungan nutrisi dalam daging (Romans et al. 1985). Kebusukan ini identik dengan adanya aktivitas bakteri pembusuk yang sudah berkembang relatif besar pada daging saat sampai ke tangan konsumen, mengakibatkan kerusakan daging di tandai oleh terbentuknya senyawa berbau busuk seperti amonia $\mathrm{H}_{2} \mathrm{~S}$, indol dan amin, yang merupakan hasil pemecahan protein dari mikroorganisme
(Siagian 2002). Pembusukan daging juga berarti penguraian bakterial terhadap bahan-bahan organis secara intensif, yang antara lain membentuk gas-gas berbau, sehingga sangat berpengaruh terhadap turunnn ya nilai gizi dari daging. Dengan demikian, maka nilai gizi daging sapi pada saat sampai ke tangan konsumen sudah mulai berkurang, akibat dari proses pembusukan.

Gregova et al (2008), juga telah membuktikan bahwa kontaminasi mikroba telah mencemari produk sejak di rumah pemotongan ayam. Tabel 3. Menunjukkan konsentrsi sejumlah mikroba yang diambil dari beberapa peralatan di lokasi pemotongan ayam.

Data jumlah mikroba diatas diambil dari lima area yang berbeda pada RPH yaitu, area pemotongan unggas, pengeluaran jeroan, pemotongan bagian, pengemasan dan shackiling dan pengulangan sebanyak 3 kali. Pengambilan sampel udara pada setiap area diambil pada berbagai media antaranya (peralatan. meja, dinding dan lantai) yang diambil dengan spon steril. Data diatas menunjukkan bahwa bakteri udara yang tertinggi terdapat area pemotongan dan juga pada area pengeluaran jeroan (lebih tinggi dari $10^{6} \mathrm{CFU} /$ $\mathrm{m}^{3}$ ) yang terdeteksi. Konsentrasi tertinggi bakteri adalah di zona kotor, tetapi juga di area pengeluaran jeroan dimana kelembaban dan suhu yang tinggi mendukung kondisi yang cocok untuk pertumbuhan mikroba

Campylobacter spp. merupakan salah satu isolat yang sering mencemari produk daging unggas di RPA. Campylobacter spp. dapat ditemukan di organ-organ reproduksi, saluran usus dan rongga mulut manusia dan hewan, dan di bawah kondisi yang menguntungkan dapat menyebabkan penyakit (Holt et al. 2000). Pada unggas, Campylobacter spp tidak menunjukkan tandatanda penyakit, tetapi bakteri dari usus dapat mencemari permukaan karkas selama evisceration di rumah jagal dan kemudian bisa menular ke manusia. Perlu diketahui, Campylobacter spp. adalah mikroorganisme yang sangat menular dan agen penyebab paling sering infeksi usus pada manusia. Gejala klinis yang paling umum dari campylobacteriosis termasuk diare, perut sakit, demam, mual, dan kadang-kadang muntah. Gejala-gejala dapat berkisar dari ringan, parah dan apendisitis akut. Granic et al (2009) melaporkan bahwa Campylobacter tidak dicemarkan melalui air bilasan karkas unggas tetapi sebanyak $40 \%$ daging unggas ditemukan terindikasi C. Jejuni dan 26,6\% E.coli (Tabel 4). Hal ini bertentangan dengan penelitian Franchin et al. (2005), Campylobacter spp. ditemukan $25 \%$ dalam sampel air yang diuji. Hal ini terkait dengan kualitas air yang digunakan setidaknya memenuhi standar air minum.

Kontaminan bakteri, di samping berasal dari bagian

Tabel 2 Rata-rata bakteri, waktu kebusukan dan kadar VRS daging sapi yang beredar di Kota Semarang

\begin{tabular}{lccc}
\hline Variabel penelitian & \multicolumn{3}{c}{ Lokasi pengambilan sampel } \\
\cline { 2 - 4 } & $\mathrm{RPH}$ & Pedagang pasar & Konsumen \\
\hline TPC (CFU/g) & $1,04 \times 10^{7} \pm 8,19 \times 10^{6}$ & $1,22 \times 10^{8} \pm 9,25 \times 10^{7}$ & $2,77 \times 10^{8} \pm 1,37 \times 10^{8}$ \\
Uji eber (menit) & $4,139 \pm 0,588$ & $3,275 \pm 0,423$ & $2,119 \pm 0,629$ \\
VRS ( $\mu$ eq/g) & $4,72 \pm 1,437$ & $13,43 \pm 3,464$ & $18,47 \pm 5,359$ \\
\hline
\end{tabular}

SNI 01-3932-1995 TPC $=5 \times 105$ CFU/g 
Tabel 3 Konsentrasi mikroorganisme yang diisolasi dari titik rumah pemotongan ayam

\begin{tabular}{lccc}
\hline $\begin{array}{l}\text { Tempat pengambilan } \\
\text { sampel }\end{array}$ & $\begin{array}{c}\text { TCB }(\mathrm{CFU} / \\
\mathrm{m} 3)\end{array}$ & $\begin{array}{c}\mathrm{CB}(\mathrm{CFU} / \\
\mathrm{m} 3)\end{array}$ & $\begin{array}{c}\text { Moulds } \\
(\mathrm{CFU} / \mathrm{m} 3)\end{array}$ \\
\hline I. Measurament & & \\
Portioning area & $6,8 \times 10^{3}$ & $0,75 \times 10^{3}$ & $1,3 \times 10^{3}$ \\
Packaging area & $2,8 \times 10^{3}$ & $0,9 \times 10^{2}$ & 0 \\
Eviscerating area & $>10^{6}$ & $2,6 \times 10^{4}$ & $1,9 \times 10^{3}$ \\
Killing area & $>10^{6}$ & $2,5 \times 10^{4}$ & $3,8 \times 10^{3}$ \\
Shackling area & $>10^{6}$ & $2,07 \times 10^{4}$ & $>10^{4}$ \\
II. Measurament & & \\
Portioning area & $4,2 \times 10^{3}$ & $1,0 \times 10^{2}$ & $1,0 \times 10^{2}$ \\
Packaging area & $3,5 \times 10^{3}$ & $2,0 \times 10^{2}$ & $0,7 \times 10^{3}$ \\
Eviscerating area & $>10^{6}$ & $0,4 \times 10^{3}$ & $0,8 \times 10^{3}$ \\
Killing area & $>10^{6}$ & $1,8 \times 10^{4}$ & $1,0 \times 10^{3}$ \\
Shackling area & $>10^{6}$ & $5,9 \times 10^{4}$ & $2,5 \times 10^{3}$ \\
III. Measurament & & \\
Portioning area & $4,9 \times 10^{3}$ & $0,5 \times 10^{2}$ & $1,0 \times 10^{2}$ \\
Packaging area & $7,6 \times 10^{3}$ & $0,5 \times 10^{2}$ & $0,5 \times 10^{2}$ \\
Eviscerating area & $>10^{6}$ & $0,4 \times 10^{3}$ & $0,6 \times 10^{3}$ \\
Killing area & $>10^{6}$ & $1,0 \times 10^{2}$ & $1,0 \times 10^{3}$ \\
Shackling area & $>10^{6}$ & $1,0 \times 10^{2}$ & $0,5 \times 10^{3}$ \\
\hline
\end{tabular}

tubuh ternak sewaktu masih hidup, juga dapat berasal dari lingkungan sekitar tempat pemotongan. Salmonellosis merupakan salah satu kontaminan karkas dan daging yang berasal dari lingkungan proses pemotongan (Soeparno 1998), E. coli juga sering ditemukan, melalui kontaminan air baku yang tidak bersih (Koohmaraie 2005). Buckle et al. (1987) menyatakan bahwa sumber pencemaran mikroorganisme diantaranya lalat yang berasal dari tempat penyembelihan daging, tanah pada ruang penyembelihan. Sumber kontaminan juga dapat bersumber dari para pekerja $\mathrm{RPH}$ yang kurang higienis.

Mesophiles, psychrotrophs, koliform, escherichia coli dan staphylococcus aureus telah digunakan untuk menilai microbiologikal dalam produk unggas. Chaiba et al (2007) telah meneliti produk unggas yang diambil dari supermarket, Toko poulterers dan pemotongan artisanal dan pasar yang populer, yang berbeda dari satu sama lain dalam hal kondisi yang higienis dalam pemotongan dan penjualan daging unggas (Tabel 5).

Dari keempat tempat pengambilan sampel ditemukan bahwa kandungan tertinggi yaitu mesophiles. Tingkat pencemaran secara signifikan berbeda nyata
Tabel 4 Kontaminasi Camphylobacter spp yang diisolasi dari swab kulita karkas, air bilasan, dan karkas unggas

\begin{tabular}{|c|c|c|c|c|}
\hline & \multirow{2}{*}{$\begin{array}{l}\text { Jumlah } \\
\text { sampel }\end{array}$} & \multicolumn{2}{|c|}{ Hasil positif } & \multirow[t]{2}{*}{ Total } \\
\hline & & C. jejuni & C. coli & \\
\hline Swab & 75 & - & - & - \\
\hline Water & 15 & - & - & - \\
\hline Meat & 15 & $6(40,0)$ & $4(26,6)$ & $10(66,6)$ \\
\hline Jumlah & 105 & $6(6,3)$ & $4(4,2)$ & $10(10,5)$ \\
\hline
\end{tabular}

( $\mathrm{P}>0.05)$ lebih tinggi pada pasar peternakan daripada sampel yang dibeli di supermarket. Hal ini mungkin terjadi karena kondisi lingkungan kedua sampel tersebut berbeda. Secara umum mikroba penting dalam ayam namun dalam batas normal, seperti angka telah dilaporkan oleh penelitipeneliti sebelumnya. Namun pada penelitian ini jumlah psychrotrophs, E,coli, S. Aureus melewati batas wajar yang telah ditetapkan dalam pedoman (1996) CNERNA-CNRS daging unggas. Maka dari itu pada sampel yang dibeli pada pasar tradisional dan RPH artisanal dianggap sebagai kualitas tidak dapat diterima. Kedua sampel ini sangat tinggi terkontaminasi dari pada kedua sampel lainnya. Pada pasar tradisioanal dan RPH artisanal pemotongan serta penjualan dilakukan pada tempat yang sama sehingga mikroba yang terkomtaminasi pada daging ayam sangat tinggi.

Pembekuan dilakukan untuk memperpanjang masa simpan, dengan tujuan membatasi aktivitas mikroorganisme, reaksi-reaksi enzimatik, kimia dan kerusakan fisik. Karkas utuh yang disimpan pada suhu $4^{\circ} \mathrm{C}$ dapat tetap dalam keadaan baik selama tiga hari, sedangkan penyimpanan pada suhu $-32^{\circ} \mathrm{C}$ dapat bertahan sampai satu tahun dan sembilan bulan untuk karkas yang dipotong-potong (Hardjosworo dan Rukmiasih, 2000). Pembekuan komersial pada temperatur $-29^{\circ} \mathrm{C}$ dan domestik pada $-18^{\circ} \mathrm{C}$ merupakan metode standar preservasi dan produk dapat bertahan selama satu sampai dua tahun (Soeparno 2005), tetapi selama penyimpanan dapat terjadi kemunduran kualitas dibanding daging segar atau dingin. Pembekuan mampu memusnahkan sebagian besar bakteri patogen dan memperlambat/menghambat pertumbuhan sejumlah mikroorganisme. Namun pembekuan tidak membunuh semua mikroorganisme dan tidak mengakibatkan sterilisasi makanan. Mikroorganisme banyak juga dapat bertahan hidup pada proses pembekuan dan bertumbuh setelah penyegaran kembali, apalagi bila jumlah mikrobia awal tinggi. Pembekuan karkas atau daging juga tidak dianjurkan untuk waktu yang panjang karena dapat terjadi kemunduran kualitas daging.

Tabel 5 Bakteri yang ditemukan pada produk daging unggas outlet

\begin{tabular}{lcccc}
\hline Jenis bakteri & $\begin{array}{c}\text { Sampel dari Popular } \\
\text { market }\end{array}$ & Sampel dari RPA & Sampel dari Poulterers'shop & Sampel dari Supermarket \\
\hline Mesophiles & $6,18 \pm 0,55 \mathrm{a}$ & $6,14 \pm 0,69 \mathrm{a}$ & $5,42 \pm 0,33 \mathrm{~b}$ & $4,74 \pm 0,34 \mathrm{c}$ \\
Psychrotrophs & $4,48 \pm 0,27 \mathrm{a}$ & $4,36 \pm 0,30 \mathrm{a}$ & $4,07 \pm 0,34 \mathrm{~b}$ & $4,02 \pm 0,35 \mathrm{c}$ \\
Total Coliforms & $4,64 \pm 0,53 \mathrm{a}$ & $4,60 \pm 0,44 \mathrm{a}$ & $3,99 \pm 0,37 \mathrm{~b}$ & $3,54 \pm 0,27 \mathrm{c}$ \\
Fecal Coliforms & $3,89 \pm 0,42 \mathrm{a}$ & $3,61 \pm 0,40 \mathrm{a}$ & $3,10 \pm 0,46 \mathrm{~b}$ & $2,34 \pm 0,50 \mathrm{c}$ \\
Escherichia coli & $2,34 \pm 0,5 \mathrm{a}$ & $2,32 \pm 0,36 \mathrm{a}$ & $1,81 \pm 0,45 \mathrm{~b}$ & $0,70 \pm 0,34 \mathrm{c}$ \\
Staphylococcus aureus & $2,43 \pm 0,49 \mathrm{a}$ & $2,42 \pm 0,42 \mathrm{a}$ & $1,87 \pm 0,79 \mathrm{~b}$ & $0,68 \pm 0,72 \mathrm{c}$ \\
\hline
\end{tabular}




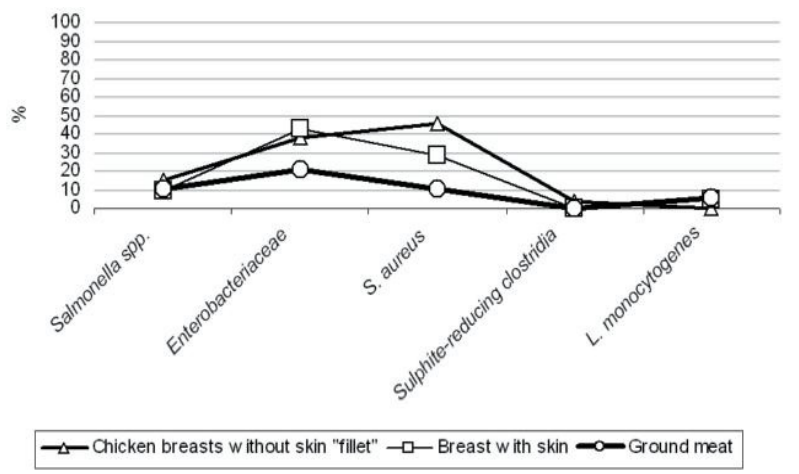

Gambar 3 Hasil analisis bakteri pada retail cut dan daging ayam beku

Kozačinski et al. (2006) melaporkan bahwa temuan cemaran mikroba pada daging beku lebih rendah dibandingkan pada potongan daging ayam bagian dada tanda kulit (pilet) dan dada dengan kulit. . Daging ayam "ground" telah dibekukan di deep-freezers (suhu-18 $\mathrm{C}$ ), dan daging ayam segar dalam pendingin showcase (suhu $\left.4^{0} \mathrm{C}\right)$.

Enam puluh enam sampel daging ayam yang dikumpulkan dari pengecer, 21 sampel yang dari dada ayam tanpa kulit, 19 sampel dari dada ayam dengan kulit dan 26 sampel daging ayam beku 'ground'. Hasil analisis ditemukan persentase Salmonella spp. sebesar 10,60\%; S. Auerus sebesar 30,30\%; enterobacteria sebesar 24,84\%; L. Monocytogenes sebesar 3,03\%; dan clostridium sulfat sebesar $1,5 \%$. Tidak ditemukan adanya cemaran Campylobacter spp. pada sampel yang dianalisis.

\section{KESIMPULAN}

Kontaminasipada daging dapatterjadi selama proses pembelahan karkas, pendinginan, pembekuan, penyegaran daging beku, pemotongan karkas, pembuatan produk daging olahan, pengawetan, pengepakan, penyimpanan, dan pemasarannya. Mesophiles, psychrotrophs, koliform, escherichia coli dan staphylococcus aureus telah digunakan untuk menilai mikrobiologis produk unggas Kontaminasi ini dapat diatasi atau dikurangi dengan melakukan penanganan yang higienis dengan sistem sanitasi yang sebaik-baiknya.

\section{DAFTAR PUSTAKA}

Arifin M, Dwiloka B, Patriani DE. 2008. Penurunan Kualitas Daging Sapi ynag Terjadi selama Proses Pemotongan dan Distribusi di Kota Semarang. Seminar Nasional. Semarang (ID): Universitas Diponegoro.

Brooks GF, Butel JS, Morse SA. 2005. Medical Microbiology. McGraw-Hills Companies Inc.

Buckle KA, R.A. Edward, G.H. Fleet Dan M. Wootton. 1987. Ilmu Pangan. (diterjemahkan oleh H. Purnomo dan Adiono). Jakarta (ID): Universitas Indonesia Press.

Chaiba A, Filali RF, Chahlaoui A, Bencheikh S, Zerhouni M. 2007. Microbiological quality of Poultry meat on Meknes Market (Marocco). J.Food Safety.

Direktorat Standarisasi Komoditi Pertanian. 2000. SNI 01-3932-1995 Karkas Sapi, Jakarta.

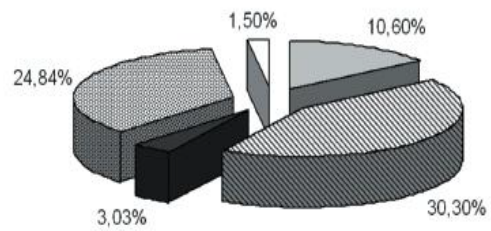

\begin{tabular}{|c|c|}
\hline $\begin{array}{l}\text { 口Salmonella spp. } \\
\text { a L. monocytogenes } \\
\text { 口sulphite-reducing clostridia }\end{array}$ & $\begin{array}{l}\text { \$S. aureus } \\
\text { —Enterobacteriaceae }\end{array}$ \\
\hline
\end{tabular}

Gambar 4 Temuan mikroba pada daging ayam $(n=66)$

Doyle MP, Beuchat LR, Montville TJ. 2001. Food Microbiology. Fundamental and Frontiers. 2nd edition. Washington DC: ASM Press.

[Dirjennak] Direktorat Jenderal Peternakan. 1992. Potensi Sub Sektor Peternakan. Jakarta: Direktorat Jenderal Peternakan.

Fardiaz S. 1993. Analisis Mikrobiologi Pangan. Jakarta (ID): Raja Grafindo Persada.

Franchin PR, Aidoo KE, Batista CR. 2005. Sources of poultry meat contamination with thermophilic campylobacter before slaughter. J. Microbioal. 36: 157162.

Granic K, KrearD, UhitilS, and JacsicS. 2009. Determination of Campylobacter spp. In Slaughterhouse and poultry meat. J. Veterinarski Arhiv. 5: 491-497.

Gregova, Venglovský, Kmet V. 2008. Microbial population and antibiotic resistance in escherichia coli isolated from poultry slaughterhouse.

Hariyadi RD. 2005. Bakteri Indikator Sanitasi dan Keamanan Air Minum. http://web.ipb.ac.id/ tpg/de/ pubde fdsf bctrindktr.php [ 5 Desember 2013]

Holt JGN, Krieg R, Sneath PHA, Stanley JT, and Williams ST. 2000. Aerobics Microaerophilic, Motile, Helical/ Vibriod Gram Negative Bacteria. In: Bergey's Manual of DeterminativeBacteriology, 9th ed. USA (Us) : Williams \& Wilkins.

Koohmaraie M. 2005. Post harvest Interventions to Reduce/Eliminate Pathogens in Beef. Meat Animal . New York (US): Research Center.

Kozacinski L, Hadziosmanovis M and Zdolec N. 2006. Microbiological quality of poultry meat on Croation market. J. Veterinarski arhiv.

Radu, Son, Mutalib, S. Abdul, Rusul, Gulam, Ahmad, Dan Zainori. 1998. Detection of Escherichia coli O157:H7 in beef marketed in Malaysia. Applied and Environmental Microbiology 64(3): 1153 - 1156.

Romans JR, WJ Costello, CW Carlson, ML Geaser, and KW Jones. 1985. The Meat We Eat. 13th Ed. The Interstate Publishers, Inc, Illinois.

Quinn PJ, Markey BK, Carter ME, Donnelly WJ, Leonard FC. 2002. Veterinary Microbiology and Microbial Disease. 2121 Steve Avenue, Ames, Iowa: Blackwell Publishing.

Shah M. 2003. Molecular Pathogenesis of Staphylococcus 
aureus and Other Staphylococci. Di dalam: Book Reading and Presentation.

Siagian A. 2002. Mikroba Patogen Pada Makanan dan Sumber Pencemarannya. Universitas Sumatera Utara (USU-press), Medan.

Soeparno. 1998. Ilmu dan Teknologi Daging. , Yogyakarta (ID): Gadjah Mada University Press.

Todar K. 2008a. Pathogenic E. coli. Todar's Online Textbook of Bacteriology. http://e.coli.html. [4 Desember 2013].

Todar K. 2008b. Salmonella and Salmonellosis. Todar's Online Textbook of Bacteriology. http://salmonella. html. [4 Desember 2013].

Todar K. 2008c. Staphylococcus aureus. Todar's Online Textbook of Bacteriology. http://salmonella.html. [4 Desember 2013]. 